\title{
AN ECONOMIC ANALYSIS OF GOVERNMENT CUSTOM HIRING SERVICES FOR DIFFERENT FARM MACHINERIES IN BHUTAN
}

\author{
N. Kinga* and W. Chetem \\ Agriculture Machinery Centre, Department of Agriculture, Bhutan
}

\begin{abstract}
Farmers in Bhutan trend to own agricultural machineries though the individual area under farm mechanization is not enough. Hiring out or in of farm machineries as a business enterprise need to be advocated. Therefore, an effort was made in this study to generate some parameters regarding farm machinery business at farm level based on practical experience. Bhutanese Government has endorsed some users' parameters including cost and return which are used to guide the custom rates for different machineries for farmers and service providers. The study's objective was to generate different empirical formula for different farm machineries which shall help to propose varying custom hiring rates based on the projected operation days based on the government endorsed parameters. It is also to ascertain whether the present rates charged by Farm Machinery Corporation Limited bring a positive return to its custom hiring business for different machines. The study revealed that the operation cost of farm machinery includes both fixed cost and variable cost. Cost, return and break-even data for different farm machineries give a confident opinion for the owners and Farm Machinery Corporation Limited (FMCL) to take up the hiring scheme as a profitable business. The custom hiring rate also gives a good guide on the custom hiring rates to be charged based on the operating days in the country. On endorsed hiring rates and parameters by government, FMCL shall be able to make a huge profit annually especially on tractors and mini combine harvesters as compared to other machineries by $\mathrm{Nu} 0.51 \mathrm{M}$ and $0.39 \mathrm{M}$ respectively. All other machines are also making a profit annually under the government endorsed parameters. However, there is also an opportunity to reduce the custom rates to bring down the overall cost of cultivation of respective crops using the machines.
\end{abstract}

Keywords: Farm machinery, Custom hiring service, Breakeven point, acre

\footnotetext{
*Corresponding author: knorbu@ moaf.gov.bt
} 
Kinga and Chetem

\section{INTRODUCTION}

Bhutan is an agrarian country with $62.2 \%$ rural population (PHCB, 2017). Unfortunately only $7.8 \%$ of the total area is under agriculture which is again driven predominantly by animal draft due to rugged terrains and unavailability of farm machinery in the country. Major efforts are being initiated by government to promote farm mechanization activities. There is huge demand for farm machinery like power tiller, tractors to be used in the primary and secondary tillage operations in the country. Still huge demand is there and farmers in majority trend to have their own machines though the individual area under farm mechanization is not high. This trend can be delinked through hiring system and equally important to let the machineries owners understand that hiring their machines to others is a business and also to educate other farmers that hiring is more advantages than owning if their individual land holdings are less. Custom hiring has the potential to be one of the most effective strategies to introduce high quality and efficient farm mechanization to the small farming structures that are widespread in many countries in the Asia-Pacific region (CSAM, 2017). There is limited and fixed time available for each operation in each season which makes it all the more imperative to calculate the machines requirement and cost of operation.

At present the hiring of farm machineries in Bhutan is not on a commercial scale and the informal hiring practiced is purely based on the convenience of the machine owners and also the rate for the hiring is based on the farmers practice and not at all calculated to accept as a realistic hiring rate. Farm Machinery Corporation Limited (FMCL) had been implementing the government hiring scheme to encourage farmers to avail this service. All the farmers who availed the hiring services found the service very beneficial (AMC, 2019). The rates are endorsed based on different parameters. All the custom hiring centres studied under the south western province under Punjab, India were running in profit (Parminder et al., 2012).

This study shall provide a guide for the private firms to relook at their hiring rates in comparison with the government hiring scheme using the empirical formula for respective farm machinery and also to observe the present hiring rate and its profitability based on government endorsed hiring parameters.

\section{MATERIALS AND METHODS}

The cost of operation of farm machinery is divided into two sub-costs (i) Fixed cost and (ii) Variable cost, where fixed cost is independent of operational use while variable cost varies proportionally with the area coverage or the machine use. Higher the machine use, higher will be the variable cost for that machine. The major components of the fixed and variable costs are given below.

1) Annual Fixed Cost

i. Depreciation cost 

ii. Interest on investment
iii. Insurance cost
iv. Shelter cost for the machine
v. Registration cost

For the implements associated with the farm machinery, it generally has depreciation and interest cost only.

2) Annual Variable Cost

i) Fuel cost

ii) Lubrication cost

iii) Labour wages

iv) Repair and maintenance cost

Calculation of the Fixed cost of the farm machinery

i) Depreciation cost: It is the measure of the amount by which value of the machine decreased with passage of time. According to Kepner et al. (2005), the annual depreciation was calculated as

$$
D=\frac{(P-S)}{L}
$$

Where, $\mathrm{D}=$ Yearly depreciation; $\mathrm{P}=$ Purchase price of the machine $(\mathrm{Nu})$, $\mathrm{S}=$ is the salvage value or the selling price of the machine after its useful use $(\mathrm{Nu})$ and assumed as $10 \%$ of the machine price; $\mathrm{L}=$ useful life of the machine between buying and selling (10 years for farm machinery).

ii) Interest on investment: It is the interest generated had the money to buy the machine is used for other purposes which would have given the maximum return. It is normally the interest amount generated from a fixed deposit. In Bhutan, the maximum interest generated through fixed deposit is 8.5\%.According to the Kepner et al. (2005) and Khairo et al. (2009) the annual interest on the investment was calculated as follows:

$$
I=\frac{(P+S)}{2} \times \frac{i}{100}
$$

Where, $\mathrm{I}=$ Rate of interest in $\%, \mathrm{i}=$ Annual interest rate for buying a machinery

iii) Machinery shed (shelter): This is the cost associated with having a shed used primarily to house the machinery. Shelter cost has been calculated at $1.5 \%$ of the purchase price of the machine.

$$
S c=\frac{1.1 P}{2} \times \frac{i s}{100}
$$


Where, Sc $=$ hiring rate of the shelter in $\%$, is = Hiring cost of the shelter (1.5\% per annum for the agricultural use).

iv) Insurance and taxes: It is an amount that spent on insurance every year as these machines need to be insured as they are movable machines and accident can happen anywhere any time.

$$
\text { In }=\frac{1.1 P}{2} \times \frac{i n}{100}
$$

Where, In = Rate of insurance and taxes, \%; in= Annual insurance and taxes rate ( $2 \%$ per annum for agricultural use).

v) Registration cost: This is the yearly cost incurred in registration, fitness test fee and blue book renewal of the machinery with respective authority. It is calculated as $\mathrm{Nu} 1000$ per year as the renewal and registration cost for farm machinery in Bhutan is low.

Calculation of variable costs of the farm machinery

i) Fuel cost

For simplicity, fuel cost was calculated as:

Fuel cost $\left(\mathrm{Nu} \mathrm{h}^{-1}\right)=$ fuel price $\left(\mathrm{Nu} \mathrm{L}{ }^{-1}\right) \times$ Fuel consumption $\left(\mathrm{Lh}^{-1}\right)$

ii) Lubrication oil cost

Average lubrication cost $=1.5 \%$ of fuel cost $\left(\mathrm{Nu} \mathrm{h}^{-1}\right)$

iii) Repair and maintenance cost

According to Kepner et al. (2005) it was taken $2.5 \%$ of the purchase price. However for Bhutanese terrain, it was proposed $20 \%$ as the repair needed is frequent.

$\mathrm{RM}=20 \% \times$ Purchase price of farm machinery $(\mathrm{Nu})$

iv) Operator and labour wages

The labour cost $(\mathrm{Nu})$ was the product of number of labour required for number of days for any operation and labour charges per person per day. It is assumed as $\mathrm{Nu} 700 /$ day

Labour cost $=$ Number of days $\mathrm{x}$ Labour charge $\left(\mathrm{Nu} \mathrm{d}^{-1}\right)$

v) Mathematical analysis

i) Cost of operation is the cost involved in the operation of the machine in the field

$$
\operatorname{CoO}=\frac{\text { TotalAnnualCost }\left(\frac{\mathrm{Nu}}{\text { year }}\right)}{\text { Capacityofthemachine }\left(\frac{\text { acre }}{\text { year }}\right)}
$$


Where, total annual cost includes both fixed cost and variable cost. The capacity of the machines is its performed capacity in acre/year

vi) Over head cost is inclusive of the cost involved in arranging the operation from office, power, office rent, telephone calls, the machines transportation cost to the field and off the field, etc. It is taken as $15 \%$ on the cost of operation of the machinery. In detail overhead cost of $10 \%$, contingency cost of $5 \%$ from the operation cost per day can been included in the final calculation of the cost of operation per acre.

ii) Profit margin: A profit margin needs to be built into the hiring rate to make doing the work worthwhile. The profit margin can be $10 \%$ on the cost of operation.

iii) Hiring rate: It is inclusive of the cost of operation, overhead cost involved and the profit margin. This is the rate or the charge that you ask during the hiring system which can be hour or acreage basis.

iv) Break-even point analysis

Break-even point (BEP) is the point at which the total hiring cost is exactly equal to the total costs. It was calculated in terms of the fixed cost, variable cost and hiring charges. It is frequently calculated in terms of area coverage and it is the minimum acre coverage required so that there is neither loss nor a profit from this work.

$$
B E P=\frac{(\text { Fixedcost })\left(\frac{N u}{\text { year }}\right)}{\left[(\text { Hiringcost })-(\text { Variablecost })\left(\frac{N u}{(h)(\text { acre })(\text { year })}\right)\right]}
$$

v) The hiring charges in $\mathrm{Nu} / \mathrm{h}$ and even break-even in hours can be calculated. This

can be done

$$
\text { Customrate }\left(\frac{N u}{h}\right)=\frac{N u / \text { acre }}{\text { acre } / h}
$$

Where, $\mathrm{Nu} / \mathrm{acre}$ is the custom rate in acre and acre/ $\mathrm{h}$ is the field capacity of the farm machinery.

The nationally approved parameters are based on the actual field results and experiences had been adopted for calculation. This is the standard cost analysis practiced by Farm Machinery Corporation Limited (FMCL) which is executing the national hiring scheme in the country. The private individuals are also practicing the hiring though in very limited numbers as shown in Table 1. 
Table 1. Hiring cost parameters for custom hiring analysis

\begin{tabular}{|c|c|c|c|c|c|c|c|c|c|}
\hline Description & $\begin{array}{l}\text { Power } \\
\text { tiller }\end{array}$ & $\begin{array}{c}\text { Tractor } \\
\text { above } \\
34 \mathrm{hp}\end{array}$ & $\begin{array}{l}\text { Tractor } \\
34 \mathrm{hp}\end{array}$ & $\begin{array}{l}\text { Tractor } \\
18 \mathrm{hp}\end{array}$ & $\begin{array}{l}\text { Paddy } \\
\text { reaper }\end{array}$ & $\begin{array}{l}\text { Combine } \\
\text { harvester }\end{array}$ & $\begin{array}{c}\text { Paddy } \\
\text { Transplanter }\end{array}$ & $\begin{array}{l}\text { Water } \\
\text { pump }\end{array}$ & $\begin{array}{l}\text { Mini } \\
\text { Tiller }\end{array}$ \\
\hline Initial Cost & 302,839 & $1,300,000$ & $1,000,000$ & 800,000 & 130,000 & $1,300,000$ & 150,000 & 252,927 & 257,000 \\
\hline Life of machine & 10 & 10 & 10 & 10 & 6 & 10 & 6 & 10 & 10 \\
\hline $\begin{array}{l}\text { Operating } \\
\text { hours/day }\end{array}$ & 8 & 8 & 8 & 8 & 8 & 8 & 8 & 8 & 8 \\
\hline $\begin{array}{l}\text { Operating days } \\
\text { /year }\end{array}$ & 70 & 70 & 70 & 70 & 20 & 50 & 20 & 30 & 50 \\
\hline Operating hrs/year & 560 & 560 & 560 & 560 & 160 & 400 & 160 & 240 & 400 \\
\hline $\begin{array}{l}\text { Machine capacity } \\
\text { (acre/hour) }\end{array}$ & 0.10 & 0.30 & 0.25 & 0.18 & 0.30 & 0.30 & 0.30 & 0.25 & 0.06 \\
\hline $\begin{array}{l}\text { Machine } \\
\text { capacity(acre/year) }\end{array}$ & 56 & 168 & 140 & 100.8 & 48 & 120 & 48 & 60 & 24 \\
\hline
\end{tabular}

The in-depth operating and variable parameters which was endorsed by Ministry of Agriculture and Forest (MoAF) price fixation committee based on the past years operating cost and expenses in running the hiring operation were used for calculating the operating cost as shown in Table 2.

Table 2. Revised and approved parameters for operating cost

\begin{tabular}{|c|c|c|}
\hline Description & Revised criteria & Remarks \\
\hline Repair/year & $\begin{array}{l}20 \% \text { from initial } \\
\text { cost }\end{array}$ & $\begin{array}{l}\text { Spare parts and transportation are } \\
\text { expensive }\end{array}$ \\
\hline Fuel cost $(\mathrm{Nu} / \mathrm{L})$ & 60 & The current price of diesel fuel \\
\hline Lubrication cost & $1.5 \%$ of fuel cost & It's a standard requirement to change \\
\hline $\begin{array}{l}\text { Operator charge } \\
(\mathrm{Nu} / \text { day })\end{array}$ & 700 & $\begin{array}{l}\text { The labour cost in western region is more } \\
\text { expensive }\end{array}$ \\
\hline $\begin{array}{l}\text { Transportation during } \\
\text { hiring }\end{array}$ & $\begin{array}{l}10 \% \text { of operation } \\
\text { cost }\end{array}$ & Should be met from hiring \\
\hline Overhead cost & $\begin{array}{l}10 \% \text { of operation } \\
\text { cost }\end{array}$ & Previously it was very high \\
\hline Contingency cost & $\begin{array}{l}5 \% \text { of the } \\
\text { operation cost }\end{array}$ & $\begin{array}{l}\text { Accidents, natural calamities affects are } \\
\text { included }\end{array}$ \\
\hline Profit Margin & $\begin{array}{l}10 \% \text { of operation } \\
\text { cost }\end{array}$ & $\begin{array}{l}\text { Hiring should be sustainable and } \\
\text { continued }\end{array}$ \\
\hline $\begin{array}{l}\text { Total variable cost } \% \\
\text { range }\end{array}$ & $55 \%$ & \\
\hline
\end{tabular}




\section{RESULTS AND DISCUSSION}

\section{Custom hiring rates for different machines}

Agricultural work is season based and it's not year round activity. The seasons are very limited and during the season everyone wants a machine at the same time which makes it all the difficult to operate the machines for a longer time. These national hiring machines are also not allowed to be used for the non agricultural purposes and thus shall have very limited operating days. For power tillers and tractors, the operating days endorsed is 70 days and for combine harvester is 50 days as shown in Table 3. A few of the government endorsed hiring rates based on above parameters are Power tiller: $\mathrm{Nu}$ 3376/day, Tractor>34 hp; Nu12044/day, Tractor 34hp; Nu9018/day and Combine harvester; Nu 13179/day. The empirical formula for different machines in above Figures also provide a guide to project different custom rates based on the operating days which can be possible based on individual convenience by private hiring entrepreneurs

\section{Determination of economic feasibility of farm machinery}

After calculating the break-even point (BEP), it is observed that most of the farm machines under the hiring scheme have BEP more than their annual operating days and use i.e. the net annual usage of machinery after the BEP is reached is positive (where the net annual usage=annual operating days per year - BEP of machinery). If the net annual usage is positive, the hiring of that machine is positive.

At present the hiring rates based on the operating days endorsed by government for the Farm Machinery Corporation Limited (FMCL) is positive and it can make good profit if it's done as shown in Table 3. The most common machine which is power tiller fetches a profit of $\mathrm{Nu} 0.16 \mathrm{M}$ for operating days of 70 days endorsed by government. Similarly tractor of $34 \mathrm{hp}$ above power fetches the maximum of $\mathrm{Nu}$ $0.51 \mathrm{M}$ and $\mathrm{Nu} 0.37 \mathrm{M}$ for $34 \mathrm{hp}$ power tractor respectively. The combine harvester which is another very required and sought out machine by farmers fetches a profit of $\mathrm{Nu} 0.39 \mathrm{M}$ as shown.

Table 3. Break-even point analysis of farm machines

\begin{tabular}{l|c|c|c|c|c|c|c|c|c}
\hline Parameters & $\begin{array}{c}\text { Power } \\
\text { tiller }\end{array}$ & $\begin{array}{c}\text { Tractor } \\
\text { above } \\
34 \mathrm{hp}\end{array}$ & $\begin{array}{c}\text { Tractor } \\
34 \mathrm{hp}\end{array}$ & $\begin{array}{c}\text { Tractor } \\
18 \mathrm{hp}\end{array}$ & $\begin{array}{c}\text { Paddy } \\
\text { reaper }\end{array}$ & $\begin{array}{c}\text { Combine } \\
\text { harvester }\end{array}$ & $\begin{array}{c}\text { Paddy } \\
\text { Trasplanter }\end{array}$ & $\begin{array}{c}\text { Water } \\
\text { pump }\end{array}$ & $\begin{array}{c}\text { Mini } \\
\text { Tiller }\end{array}$ \\
\hline $\begin{array}{l}\text { Initial Cost ( Nu) } \\
\begin{array}{l}\text { Operating } \\
\text { days/year }\end{array}\end{array}$ & $\begin{array}{c}302,839 \\
1,300,000\end{array}$ & $1,000,000$ & 800,000 & 130,000 & $1,300,000$ & 150,000 & 252,927 & 257,000 \\
$\begin{array}{l}\text { Actual operation } \\
\text { cost/day ( Nu) }\end{array}$ & 3376 & 70 & 70 & 70 & 20 & 50 & 20 & 30 & 50 \\
$\begin{array}{l}\text { Break-even point } \\
\text { (days/year) }\end{array}$ & 22.6 & 27.9 & 28.4 & 29.0 & 9.2 & 20.3 & 9.4 & 14.1 & 15.8 \\
\hline
\end{tabular}


From the above data, the graph of annual profit or loss is plotted as shown in Figure 1. It is observed that tractors and mini combine harvesters make a maximum profit annually at the present hiring rates and the operating days for the government hiring scheme. Tractors alone make a profit of really $\mathrm{Nu} 0.51 \mathrm{M}$ in a year which necessitates the requirement to reduce the custom hiring rate for these machines for the ease to the farmers. Others machines are all making a profit which is good for the hiring scheme.

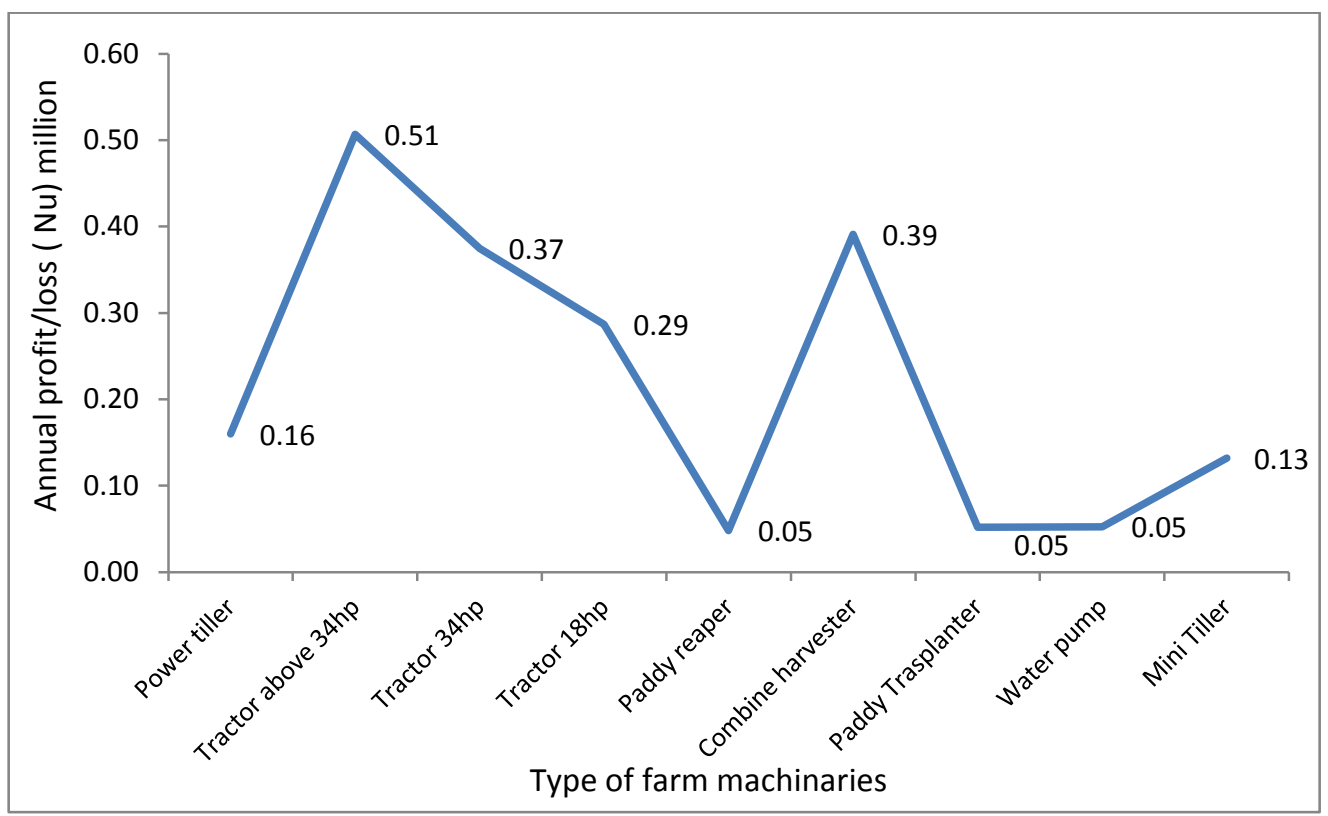

Figure 1. Annual profit/loss of various common farm machines

\section{CONCLUSION}

The results and the analysis give a confident opinion for the machine owners and FMCL to take up the hiring scheme as it is still very profitable based on the national endorsed parameters. At present endorsed hiring rates and parameters by government, FMCL is making a huge profit, especially on tractors and mini combine harvesters as compared to other machines. This is a good business for any enterprise wanting to start. However, there is also an opportunity to reduce the custom rates to bring the overall cost of cultivation of respective crops using this machine down which will benefit the marginal farmers at large. 


\section{ACKNOWLEDGEMENT}

The authors would like to acknowledge AMC for making available the endorsed parameters of the government. The author would also like to acknowledge AMC, FMCL and Department of Agriculture officials who had participated in the endorsement of the parameters which helped the authors to further analyse for the study.

\section{REFERENCES}

Agriculture Machinery Centre. (2019). Monitoring and Evaluation report on Government hiring service, AMC, DoA, Bhutan.

CSAM, December. (2017). Policy Brief: Policy Priorities for promoting Custom Hiring of Agricultural Machinery. Issue No.2. CSAM,ESCAP, United Nations.

Kepner, R.A., Bainer, R. and Barger, E.L. (2005). Principles of Farm Machinery. CBS publishers \& Distributers, Darya Ganj, New Delhi. 32-35.

National Statistics Bureau of Bhutan. (2017). Population and Housing Census of Bhutan, National Report, 2017. PHCB, NSB, Bhutan.

Parminder, K., Rohinish, K. and Anoop, D. (2012). Farm machinery services provided by selected cooperative societies. AgricEngInt: CIGR Journal, Vol. 14, No.4 123.

Salahadin, K. and Davies, L. (2009). Guide to machinery costs and contract rates. Primefacts. WWW.INDUSTRY.NSW.GOV.AU

Senthil, S. Maden, L. and Singh, N.R. (2010). Engineering Economics and Cost Analysis. Lakshimi Publications, Chennai-600 100. 